WARSZTATY Z GEOGRAFII TURYZMU

ISBN 978-83-7525-925-4 $\quad$ s. $257-270$

http://dx.doi.org/10.18778/7525-925-4.18

Sylwia GRAJA-ZWOLIŃSKA

Aleksandra SPYCHAŁA

Uniwersytet Przyrodniczy w Poznaniu

\title{
NADGOPLAŃSKI PARK TYSIĄCLECIA - OCENA ATRAKCYJNOŚCI TURYSTYCZNEJ W ASPEKCIE JEDNAKOWEJ TOPONIMII
}

\section{Wprowadzenie}

Województwo wielkopolskie to obszar kojarzony głównie z funkcjami rolniczą i przemysłowa, aczkolwiek jest on bardzo heterogeniczny, jeśli rozpatrywać go ekonomicznie, przyrodniczo i kulturowo. W krajobrazie naturalnym najczęściej występują płaskie lub faliste wysoczyzny i równiny, zdominowane przez rozległe pola oraz duże kompleksy leśne. Ponadto na terenie województwa znajduje się blisko 1000 jezior o powierzchni powyżej 1 ha, lecz ich rozmieszczenie jest nierównomierne (ŁĘCKI, red. 2010).

Bardzo cenny dla atrakcyjności turystycznej regionu jest system obszarów chronionych, a szczególnie parki krajobrazowe, które są terenami predestynowanymi do rozwoju funkcji turystycznej. W województwie wielkopolskim jest obecnie 13 parków krajobrazowych obejmujących 179410,6 ha powierzchni, co stanowi ok. $6 \%$ tej jednostki terytorialnej; jest to wynik mniejszy od średniej dla Polski, oscylującej wokół 8\% (SPYCHAŁA 2010). Jak widać na rys. 1, rozmieszczenie parków krajobrazowych jest bardzo nierównomier- 
ne - np. brak tej formy ochrony przyrody w północnej części regionu - być może za sprawą planowanego parku krajobrazowego, który obejmie Dolinę Noteci; mankament ten zostanie wkrótce wyeliminowany.

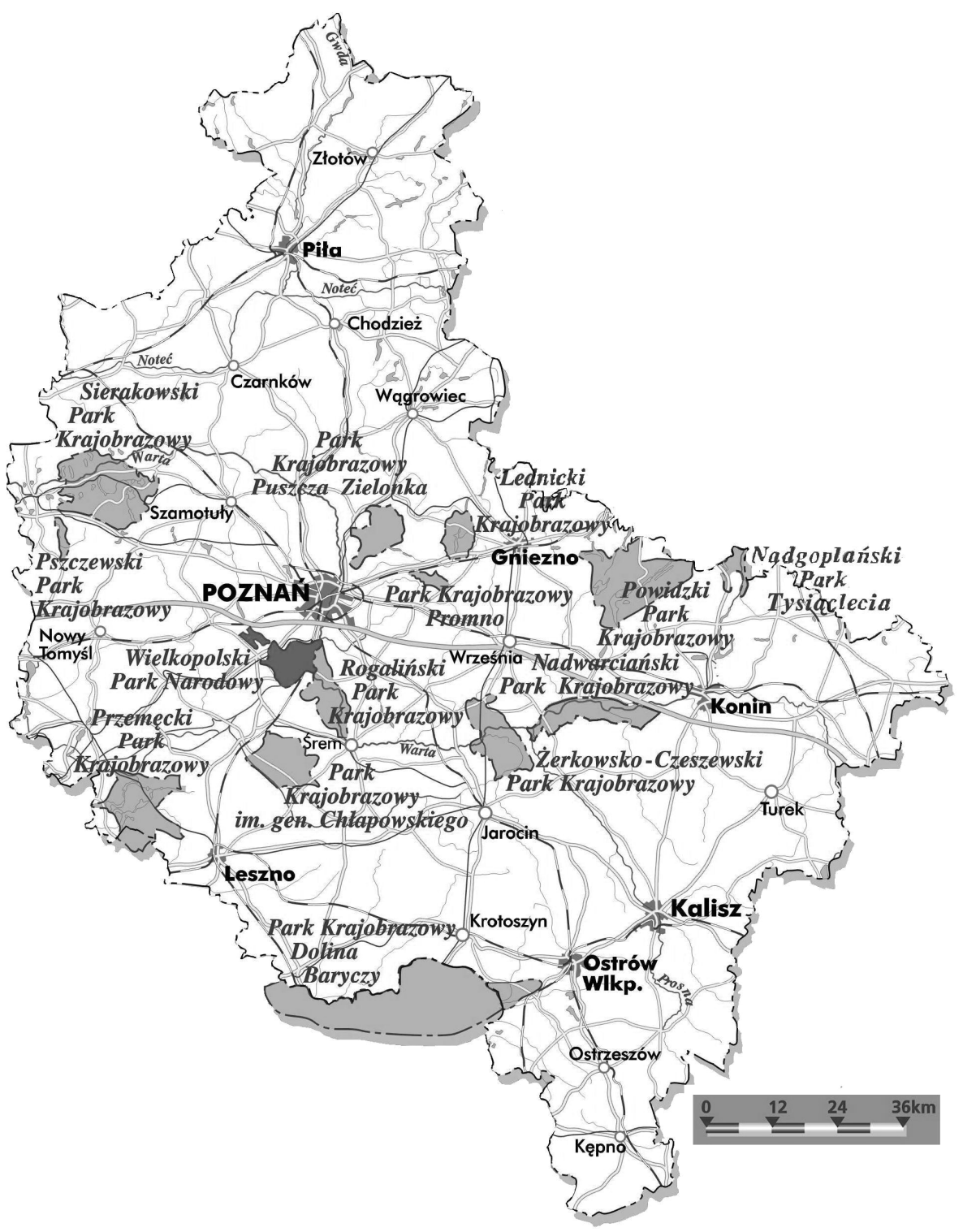

Rys. 1. Lokalizacja wielkopolskich parków krajobrazowych

Źródło: Zespół Parków Krajobrazowych Województwa Wielkopolskiego w Poznaniu 
Najmłodszym parkiem krajobrazowym województwa wielkopolskiego jest Nadgoplański Park Tysiąclecia ${ }^{1}$, utworzony w 2009 r. Warto dodać, że obiekt ten powstał dzięki zlikwidowaniu rezerwatu o identycznej nazwie. W tym miejscu po raz pierwszy pojawia się konfuzja językowa, która nawet doświadczonych krajoznawców i miłośników Wielkopolski sprowadza na manowce, a raczej na teren innego województwa - kujawsko-pomorskiego², ponieważ w obrębie tegoż istnieje także Park Krajobrazowy "Nadgoplański Park Tysiąclecia", wprowadzając w nomenklaturze, a co najistotniejsze W świadomości potencjalnych i nawet rzeczywistych turystów - kompletne zamieszanie, potęgowane dodatkowo przez ten sam symbol obu parków, którym jest gęś gęgawa.

Autorki niniejszego opracowania mają na celu określenie znajomości owych obszarów chronionych oraz ocenę ich atrakcyjności turystycznej w kontekście identycznej nomenklatury.

Wielkopolski NPT zajmuje powierzchnię 3074,59 ha i administracyjnie przynależy do jednej gminy położonej w powiecie konińskim - Skulska. Celem jego ochrony jest utrzymanie dogodnych warunków bytowania dla wielu gatunków ptaków (głównie wodnych i błotnych) oraz zachowanie naturalnie ukształtowanego krajobrazu polodowcowego. Obszar parku jest zarządzany przez Zespół Parków Krajobrazowych Województwa Wielkopolskiego z siedzibą w Poznaniu.

Walory kulturowe parku tworzą: gotycki kościół pw. św. Stanisława z XV w. w Warzymowie, świątynia pw. Narodzenia NMP w Skulsku ze słynącą łaskami gotycką pietą (jako że postać Matki Boskiej ukazała się według legendy żołnierzom Bolesława Chrobrego, jest to sanktuarium służb mundurowych) (ŁĘCKI 2010), pałacyk w Lisewie oraz dworek w Galiszewie. Należy dodać, że właśnie w Warzymowie (albo pobliskiej Goplanie) mieli narodzić się legendarny protoplasta rodu Piastów - Kołodziej i jego żona, Rzepicha (Polska niezwykła... 2008).

Ciekawą formę dziedzictwa niematerialnego stanowi kmina ochweśnicka - żargon, powstały w 1. połowie XIX w. na granicy zaborów rosyjskiego i pruskiego w rejonie Skulska i Ślesina. Początkowo posługiwali się

\footnotetext{
${ }^{1}$ Nazwa Park Krajobrazowy „Nadgoplański Park Tysiąclecia” w niniejszym opracowaniu jest równoznaczna z akronimem NPT.

${ }^{2}$ W Kanonie krajoznawczym województwa wielkopolskiego (ŁĘCKI, red. 2010) w opisie wielkopolskiego NPT niektóre informacje dotyczą tej formy ochrony przyrody, ale położonej na terenie województwa kujawsko-pomorskiego!
} 
nim handlarze świętymi obrazami (ochweśnik to w języku tym właśnie tzw. obraźnik) (REINFUSS 1962), a potem i sprzedający gęsi oraz pierze - przemyt $\mathrm{w}$ tym rejonie kwitł na olbrzymią skalę (JANUSZKIEWICZ, PLESKACZYŃSKI 2006).

Warto nadmienić, iż park ten charakteryzuje się dobrą dostępnością wewnętrzną - turyści mogą korzystać m.in. z Bursztynowego Szlaku Rowerowego oraz z drogi wodnej - Kanału Warta - Gopło (http://zpkww.pl/down load/128.png; 10.11.2012).

Z kolei Nadgoplański Park Tysiąclecia - park krajobrazowy na terenie województwa kujawsko-pomorskiego, mający powierzchnię 9983 ha, utworzono w 1992 r. W ujęciu administracyjnym w skład tego parku weszły tereny należące do trzech gmin: Kruszwica, Jeziora Wielkie, Piotrków Kujawski. Historia ochrony sięga tu lat 60. XX w., kiedy założono wspomniany wcześniej rezerwat o nazwie identycznej do obecnej nazwy parku krajobrazowego. Obszar zarządzany jest przez dyrektora, którego siedziba znajduje się w Kruszwicy.

Przedmiot ochrony obszarowej jest bardzo podobny do parku wielkopolskiego, tutaj jednak dodatkowo ujęto dziedzictwo historyczne, związane z początkiem polskiej państwowości. Kujawski NPT może poszczycić się pewną osobliwością florystyczną którą stanowią siedliska roślinności kserotermicznej oraz halofitów.

Walory kulturowe koncentrują się głównie w obrębie Kruszwicy. Romańska kolegiata pw. św. św. Piotra i Pawła z XII w. to najlepiej zachowana bazylika okresu romańskiego w Polsce (ŚWIECHOWSKI 1982), zaś Mysia Wieża stanowi pozostałość zamku kazimierzowskiego z XIV w. (GRZEŚKOWIAK 1965). Dziś jest to najbardziej rozpoznawalne miejsce nad Gopłem, znane także z legendy o królu Popielu, stanowiące jednocześnie znakomity punkt widokowy.

$\mathrm{Na}$ obszarze tego parku występują cztery ścieżki dydaktyczne o charakterze przyrodniczo-historycznym. Poznanie walorów terenu umożliwia również m.in. Szlak Piastowski oraz szlak turystyczny (pieszo-rowerowy) dookoła Gopła (http://kruszwica.um.gov.pl/szlaki_turystyczne;12.11.2012 r.).

Jak więc wynika już z bardzo ogólnego opisu, terytoria obu parków są bardzo do siebie podobne - zarówno pod względem przyrodniczym, jak i kulturowym. Celem pracy jest zbadanie faktycznej atrakcyjności obu form, by jednoznacznie odpowiedzieć na pytanie, czy warto, by takie obszary, zwłaszcza o takiej samej nazwie, funkcjonowały jako oddzielne jednostki? 
Fakt ich istnienia prowadzić może bowiem nie tylko do strat finansowych, ale przede wszystkim do pomyłek. Tę kwestię autorki spróbowały zdiagnozować za pomocą sondażu.

\section{Metody badawcze}

By zrealizować obrany cel pracy, wykorzystano dwie podstawowe metody badawcze. Pierwszą z nich jest ankieta, zwana również metodą badania opinii społecznej (SZTUMSKI 1984). W celu zbadania świadomości reprezentacji młodego pokolenia społeczeństwa Wielkopolan na temat NPT sporządzono kwestionariusz zawierający siedem krótkich pytań dotyczących wielkopolskich parków krajobrazowych, a w szczególności właśnie Nadgoplańskiego Parku Tysiąclecia. Sondaż przeprowadzono w październiku 2012 r. wśród studentów kierunków turystycznych Uniwersytetu Przyrodniczego w Poznaniu. Zebrano 195 kwestionariuszy, z czego do dalszej analizy zakwalifikowano 186. ( $Z$ powodu nierównomiernego rozkładu próby pominięto analizę zależności na poziomie poszczególnych roczników).

Z kolei do obiektywnej oceny atrakcyjności turystycznej NPT wykorzystano zmodyfikowaną metodę wielowymiarowej analizy porównawczej, opartej na zasadach przedstawionych przez G. Gołembskiego wraz z zespołem (1999), ze względu na możliwość uzyskania oceny dla gminy, która w tym przypadku jest jednostką badawczą. Ponadto w metodzie tej zastosowano wiele danych - tutaj zwanych wskaźnikami cząstkowymi lub cechami - odnoszących się właśnie do kwestii ochrony środowiska. Należy dodać, że metoda analizy porównawczej jest często stosowana w badaniach geograficznych dotyczących turystyki (ZAJADACZ 2003).

Mimo że jedną z najczęściej stosowanych metod oceny atrakcyjności turystycznej jest metoda bonitacji punktowej, zastosowana po raz pierwszy przez S. Leszczyckiego już w okresie międzywojnia (GOŁEMBSKI 1999), to równie często geografowie negują ją ze względu na bardzo subiektywny jej charakter. Z kolei inne metody kwestionuje się, gdyż pomijają $\mathrm{w}$ ocenie zagadnienia związane ze stopniem degradacji środowiska przyrodniczego (SOŁOWIEJ 1992). 


\section{Park Krajobrazowy „Nadgoplański Park Tysiąclecia” w świadomości studentów Uniwersytetu Przyrodniczego w Poznaniu}

Autorki za istotne uznały zbadanie wiedzy i opinii studentów Uniwersytetu Przyrodniczego (kierunków i specjalności związanych z turystyką), założyły bowiem, że reprezentanci tej uczelni powinni dysponować większą wiedzą na temat obszarów chronionych.

W pierwszej części kwestionariusza respondenci mieli wskazać właściwą liczbę parków krajobrazowych w Polsce (rys. 2). Ponad połowa badanych (66\%) odpowiedziała prawidłowo, a $24 \%$ wskazało, że jest ich więcej - około 220. Natomiast $10 \%$ badanych studentów wybrało odpowiedź sugerującą istnienie blisko 70 tego rodzaju obszarów chronionych (warto dodać, że wskaźnik błędnych odpowiedzi dotyczył głównie studentów niższych roczników).

Bardzo istotna z punktu widzenia niniejszego opracowania była kwestia istnienia parków o tej samej nazwie. By ułatwić rozwiązanie problemu, które - jak założyły autorki - będzie trudne, podano kafeterię odpowiedzi. Niestety, niewiedzą w tym zakresie (a tym samym i błędnym typowaniem) wykazało się aż 60\% ankietowanych (rys. 2). Jedynie 40\% respondentów wskazało na Nadgoplański Park Tysiąclecia.

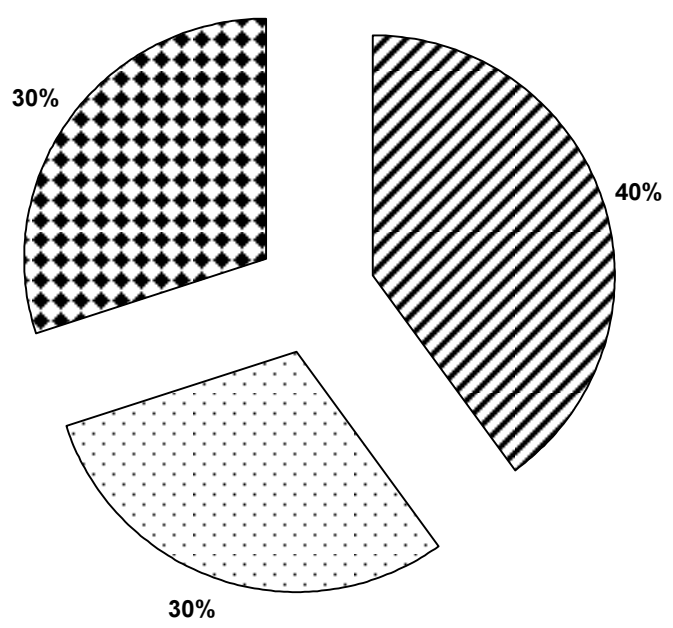

\section{$\square$ NPT ๑Promno DStawki}

Rys. 2. Wiedza studentów na temat istnienia w Polsce parków krajobrazowych o tej samej nazwie Źródło: opracowanie własne 
W dalszej części kwestionariusza respondenci byli pytani o opinie na temat celowości tworzenia dwóch odrębnych obszarów, bezpośrednio ze sobą sąsiadujących, o tej samej nazwie (rys. 3). Blisko połowa była zdecydowanie przeciwna takiemu działaniu, a aż 35\% nie miała zdania na ten temat. Jedynie $16 \%$ ankietowanych wyraziło poparcie dla tego typu idei.

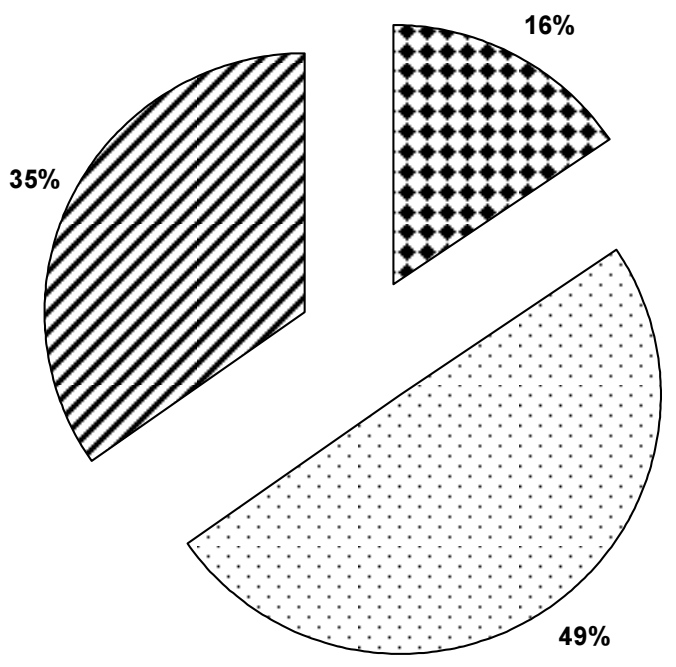

\section{tak $\square$ nie $\square$ nie wiem}

Rys. 3. Celowość tworzenia odrębnych obszarów chronionych o tej samej nazwie w opinii badanych studentów

Źródło: opracowanie własne

Na kolejnym etapie badań ankietowani mieli dopasować podane nazwy obszarów chronionych (wszystkich parków krajobrazowych i narodowych występujących na terenie województwa wielkopolskiego) do punktów na mapie (rys. 4). Respondenci najczęściej prawidłowo zaznaczali parki narodowe ( $28 \%$ ogółu udzielonych prawidłowych odpowiedzi), spośród parków krajobrazowych natomiast najbardziej rozpoznawalne okazały się: Dolina Baryczy (11,04\% odpowiedzi), Puszcza Zielonka (9,38\%), Nadgoplański Park Tysiąclecia (8,54\%) oraz Rogaliński Park Krajobrazowy (8,33\%). Najmniej trafnych odpowiedzi przypadło na Pszczewski Park Krajobrazowy $(0,83 \%)$.

W trakcie badań analizowano również znajomość istnienia transgranicznych parków krajobrazowych na terenie województwa wielkopolskiego. Kwestia ta ukazała dużą rozbieżność odpowiedzi. Z jednej strony aż 53\% badanych zdawało sobie sprawę z ich obecności i podawało konkretne przykłady. Co ciekawe, obok Parku Krajobrazowego „Dolina Baryczy” (wymienianego najczęściej), zwykle pojawiał się NPT. Jednak z drugiej strony 42\% 
studentów nie wiedziało, czy na terenie województwa wielkopolskiego występują parki o charakterze transgranicznym. Ich obecność zdecydowanie zanegowało $5 \%$ badanych.

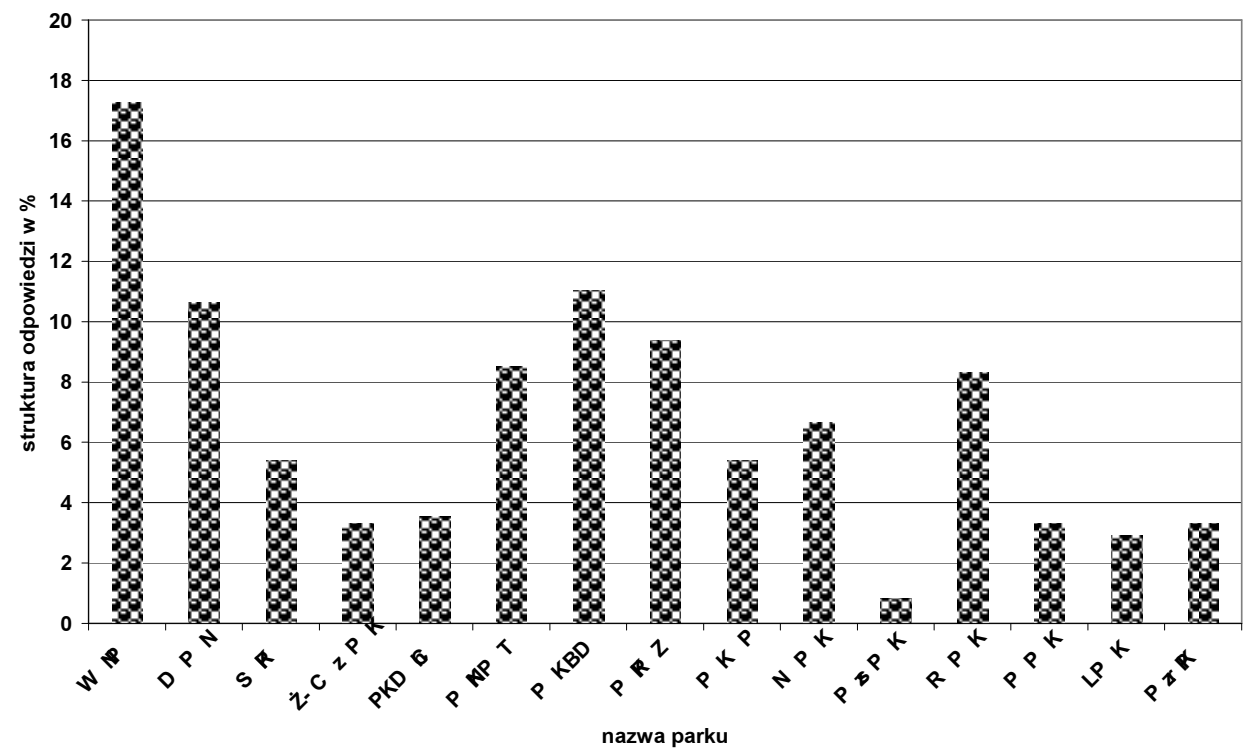

$$
\begin{aligned}
& \text { PKP - Park Krajobrazowy „Promno } \\
& \text { NPT - Nadwarciański Park Krajobrazowy } \\
& \text { PszPK - Pszczewski Park Krajobrazowy } \\
& \text { RPK - Rogaliński Park Krajobrazowy } \\
& \text { PPK - Powidzki Park Krajobrazowy } \\
& \text { LPK - Lednicki Park Krajobrazowy } \\
& \text { PrzPK - Przemęcki Park Krajobrazowy }
\end{aligned}
$$

Rys. 4. Wiedza respondentów na temat występowania obszarów chronionych na terenie województwa wielkopolskiego

Źródło: opracowanie własne

Analizując dalej podstawową wiedzę dotyczącą wielkopolskich parków krajobrazowych, zapytano również o najmłodszy tego typu obszar chroniony. Prawidłowej odpowiedzi, ze wskazaniem na NPT, udzieliło 45\% studentów (rys. 5).

Ciekawych spostrzeżeń dostarczyło pytanie na temat walorów kojarzonych z wielkopolskim Nadgoplańskim Parkiem Tysiąclecia (rys. 6). Otóż respondenci najczęściej wskazywali na jezioro Gopło (31\% ogółu odpowiedzi) 
oraz na obiekty zabytkowe w Kruszwicy (Mysia Wieża - 24\%, romańska kolegiata $-15 \%$ ). Na kolejnym miejscu wymieniano bogatą awifaunę obszaru. Jedynie nieliczni potrafili wskazać właściwe dla wielkopolskiego parku walory kulturowe (związane z miejscowością Skulsk czy Warzymowo).

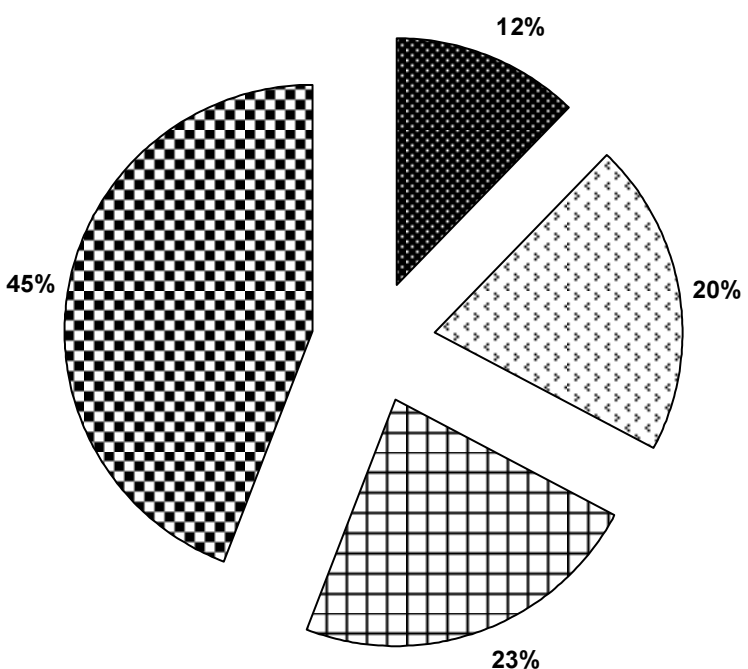

Q Nadwarciański DPromno 田Puszcza Zielonka DNPT
Rys. 5. Najmłodszy park krajobrazowy województwa wielkopolskiego według badanych studentów

Źródło: opracowanie własne

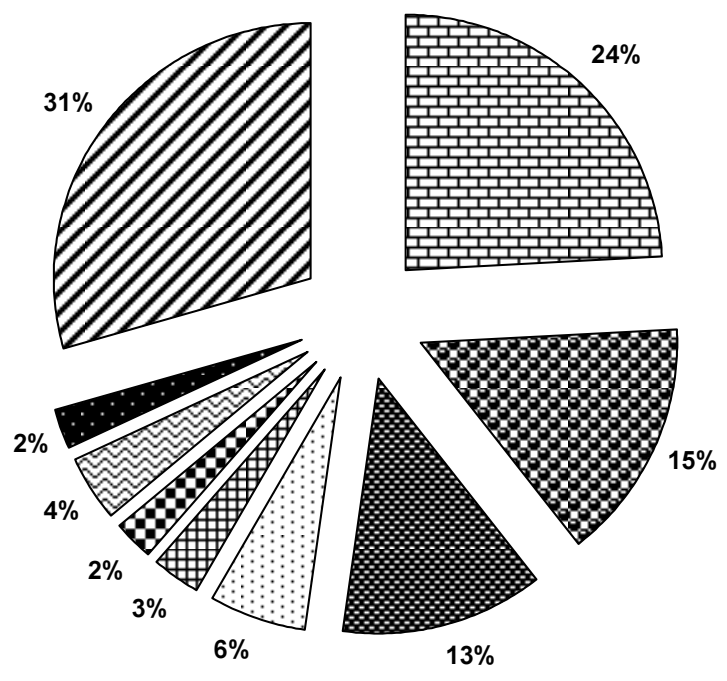

国a

Objaśnienia:

a-Mysia Wieża w Kruszwicy,

b - romańska kolegiata w Kruszwicy,

c-bogata awifauna,

d- rośliny kserotermiczne i stonolubne,

e-Kalwaria Skulska,

f-gotycki kościół w Warzymowie,

g-kmina ochweśnicka,

$\mathrm{h}$ - sanktuarium maryjne służb mundurowych w Skulsku,

i - jezioro Gopło

Rys. 6. Walory kojarzone z Parkiem Krajobrazowym „Nadgoplański Park Tysiąclecia" w opinii badanych studentów

Źródło: opracowanie własne 
Wyniki przeprowadzonych badań dostarczyły ciekawych kluczowych spostrzeżeń:

- powierzchowna znajomość zagadnień dotyczących wielkopolskich parków krajobrazowych (wynikająca po części z niewystarczającej liczby zajęć poświęconym obszarom chronionym oraz braku rozwiniętych zainteresowań krajoznawczych);

- niewielka rozpoznawalność sąsiadujących ze sobą dwóch odrębnych parków krajobrazowych o tej samej nazwie.

W kontekście poczynionych obserwacji warto się zastanowić, jakich wniosków dostarczyłyby analogiczne badania przeprowadzone na większą skalę, wśród ogółu mieszkańców Wielkopolski. Czy powszechna wiedza na temat istoty i zasad funkcjonowania parków krajobrazowych jest wystarczająca, by tworzyć odrębnie zarządzane obszary o tej samej nazwie, czy przysłuży się to do wypromowania ich walorów?

\section{Obiektywna ocena atrakcyjności turystycznej Nadgoplańskich Parków Tysiąclecia}

Jak wspomniano na wstępie pracy, zobiektywizowaną ocenę atrakcyjności turystycznej oparto na metodzie wielowymiarowej analizy porównawczej według G. GOŁEMBSKIEGO (1999). Wskaźniki przypisano następującym działom: walory turystyczne, stan i ochrona środowiska, zagospodarowanie turystyczne oraz dostępność komunikacyjna (tab. 1). Obliczony miernik atrakcyjności turystycznej może przyjmować wartości mieszczące się $\mathrm{w}$ przedziale od 0 do 1, przy czym wartość 1 oznacza maksymalny teoretyczny stopień atrakcyjności, a wartość 0 utożsamiana jest $\mathrm{z}$ brakiem atrakcyjności.

Na kanwie zgromadzonych danych i sporządzonych szacunków, których ostateczne wyniki zebrano $\mathrm{w}$ tab. 2, za najbardziej atrakcyjną gminę uznano Jeziora Wielkie. Swą dominującą pozycję w rankingu gmin nadgoplańskich zawdzięczają najbardziej rozwiniętej bazie noclegowej. Jest tu zarówno najwięcej obiektów (7), jak i miejsc do spania (570). Korzystających z noclegów było co prawda o połowę mniej niż w gminie Kruszwica, jednak liczba samych noclegów jest o ponad 1/4 wyższa. Można zatem wnioskować, iż na terenie Jezior Wielkich dominuje turystyka wypoczynkowa, zwłaszcza w okresie urlopowym (średnia długość pobytu to około siedem dni), szcze- 
gólnie biorąc pod uwagę najwyższą spośród wszystkich pozostałych jednostek lesistość gminy. Godny wspomnienia jest także stosunkowo duży odsetek obszarów chronionych $(33,3 \%)$ - druga wartość po gminie Skulsk. Niestety, na terenie omawianej gminy jest bardzo mało zabytków (3); zanotowano także zupełny brak placówek muzealnych. Z drugiej strony jednostka charakteryzuje się bardzo dobrą dostępnością komunikacyjną. Również wartość parametrów związanych ze środowiskiem naturalnym jest imponująca ogólnie w tej kategorii wygrała gmina Skulsk, natomiast Jeziora Wielkie mogą poszczycić się najlepszą przepustowością oczyszczalni ścieków.

Tabela 1. Mierniki atrakcyjności turystycznej i ich wagi

\begin{tabular}{|c|c|}
\hline \multicolumn{2}{|r|}{ Atrakcyjność turystyczna } \\
\hline Dział [waga] & Wskaźniki (cechy) [waga] \\
\hline $\begin{array}{l}\text { I. } \\
\text { Walory turystyczne } \\
{[0,4]}\end{array}$ & $\begin{array}{l}\text { - lasy (ha/powierzchnię gminy w ha) }[0,25] \\
\text { - } \text { tąki i pastwiska (ha/powierzchnię gminy w ha) }[0,1] \\
\text { - zabytki (liczba/10km² gminy) }[0,3] \\
\text { - muzea (liczba/10km² gminy) }[0,15] \\
\text { - obszary chronione (ha/powierzchnię gminy w ha x } 100 \%)[0,2] .\end{array}$ \\
\hline $\begin{array}{l}\text { II. } \\
\text { Stan i ochrona } \\
\text { środowiska } \\
{[0,3]}\end{array}$ & $\begin{array}{l}\left.\text { - odpady składowane w ciągu roku (tysiące ton } / \mathrm{km}^{2}\right)[0,3] \\
\text { - przepustowość oczyszczalni ścieków }\left(\mathrm{dm}^{3} / \mathrm{rok} / \mathrm{sscieki}^{\circ} \text { ogółem w dm } \mathrm{dm}^{3}\right)[0,3] \\
\text { - redukcja zanieczyszczeń biologicznych BZT } \mathrm{Bg} / \mathrm{rok})[0,2] \\
\text { - redukcja zanieczyszczeń chemicznych ChZT }(\mathrm{kg} / \mathrm{rok})[0,2]\end{array}$ \\
\hline $\begin{array}{l}\text { III. } \\
\text { Zagospodarowanie } \\
\text { turystyczne } \\
{[0,15]}\end{array}$ & - miejsca noclegowe (liczba/1 km² gminy) [1] \\
\hline $\begin{array}{l}\text { IV. } \\
\text { Dostępność komuni- } \\
\text { kacyjna } \\
{[0,15]}\end{array}$ & - drogi krajowe $\left(\mathrm{km} / 10 \mathrm{~km}^{2}\right)[1]$ \\
\hline
\end{tabular}

Źródło: opracowanie własne na podstawie: G. GOŁEMBSKI (1999).

Na drugim miejscu uplasowała się wielkopolska gmina Skulsk, jednak należy zaznaczyć, że ogólna ocena atrakcyjności turystycznej była w tym przypadku zdecydowanie niższa. Jednostka ta posiada bardzo dobre wskaźniki opisujące przede wszystkim stan i ochronę środowiska - w przypadku ilości składowanych odpadów i redukcji zanieczyszczeń biologicznych wiedzie prym. Podobnie jest zresztą jeśli chodzi o powierzchnię obszarów chronionych - zajmują one prawie 70\% jej terytorium. Pozostałe cechy mają war- 
tości wskaźników również wysokie, z wyjątkiem najniższej wartości zagospodarowania turystycznego - znajduje się tu tylko jeden obiekt dysponujący 16 miejscami noclegowymi. Jednak - co ciekawe - turyści spędzają tu średnio aż 11 dni! Jest to najlepszy wynik w tej kategorii.

Tabela 2. Mierniki syntetyczne (wyniki końcowe) działów wpływających na atrakcyjność turystyczną gmin, do których administracyjnie przynależą wielkopolski i kujawsko-pomorski NPT (rok 2011)

\begin{tabular}{|l|c|c|c|c|c|}
\hline \multicolumn{1}{|c|}{ Dmina } & $\begin{array}{c}\text { Walory } \\
\text { turystyczne }\end{array}$ & $\begin{array}{c}\text { Stan } \\
\text { i ochrona } \\
\text { środowiska }\end{array}$ & $\begin{array}{c}\text { Zagospo- } \\
\text { darowanie } \\
\text { turystyczne }\end{array}$ & $\begin{array}{c}\text { Dostępność } \\
\text { komunika- } \\
\text { cyjna }\end{array}$ & $\begin{array}{c}\text { Atrakcyjność } \\
\text { turystyczna }\end{array}$ \\
\hline Kruszwica & $\mathbf{0 , 8 4 9}$ & 0,132 & 0,170 & $\mathbf{1}$ & $\mathbf{0 , 5 5 5}$ \\
\hline Jeziora Wielkie & 0,448 & 0,802 & $\mathbf{1}$ & 0,960 & $\mathbf{0 , 7 1 4}$ \\
\hline Piotrków Kujawski & 0,278 & 0,924 & 0,420 & 0 & $\mathbf{0 , 4 5 1}$ \\
\hline Skulsk & 0,372 & $\mathbf{0 , 9 7 4}$ & 0,040 & 0,950 & $\mathbf{0 , 5 9 0}$ \\
\hline
\end{tabular}

Źródło: opracowanie własne na podstawie danych GUS.

Gmina Kruszwica została sklasyfikowana na miejscu trzecim. Mimo wzorcowego wskaźnika dotyczącego dostępności komunikacyjnej, a także najwyższego - walorów turystycznych, gminę tę charakteryzują najsłabsze wyniki jeśli chodzi o stan i ochronę środowiska przyrodniczego. Na pewno najistotniejszy wpływ na ten fakt ma obecność miasta Kruszwica, liczącego ponad 9 tys. mieszkańców, oraz najwyższa gęstość zaludnienia. Na terenie miasta i samej gminy dominuje turystyka tranzytowa, a także turystyka kulturowa o charakterze krótkotrwałym - średni czas pobytu to tylko nieco ponad dwa dni.

Gmina Piotrków Kujawski okazała się najmniej atrakcyjna turystycznie, przede wszystkim ze względu na najsłabszą dostępność komunikacyjna, a także nie najlepsze walory turystyczne. Natomiast wart podkreślenia jest wysoki poziom wskaźników dotyczących środowiska przyrodniczego oraz zagospodarowania turystycznego. Główny Urząd Statystyczny wskazuje na istnienie czterech obiektów dysponujących 68 miejscami noclegowymi, zaś średnia długość pobytu turysty wynosi około $10 \mathrm{dni}$.

Wyniki wielowymiarowej analizy porównawczej mogą wydać się zaskakujące - wszak to gmina Kruszwica kojarzy się powszechnie z Nadgoplem, uważana jest też za jego najbardziej atrakcyjną część. Przekonanie to oparte jest jednak tylko na obecności walorów turystycznych (zwłaszcza kulturo- 
wych). Najsłabszy punkt tej jednostki administracyjnej to ochrona środowiska, która na obszarze parku krajobrazowego powinna być szczególnie kultywowana.

Reasumując można stwierdzić, że wszystkie gminy obu NPT mają bardzo zbliżony poziom atrakcyjności turystycznej. Po raz kolejny zatem pojawia się pytanie o sens istnienia $\mathrm{w}$ odrębnej postaci tych tak podobnych do siebie obszarów chronionych.

\section{Podsumowanie}

Mimo że wyniki sondażu pokazały, iż respondenci - częściowo przynajmniej - mają świadomość istnienia dwóch parków krajobrazowych o tej samej nazwie, to należy pamiętać, iż jest to bardzo specyficzna grupa, która z obowiązku niejako powinna mieć taką wiedzę.

Badanie atrakcyjności turystycznej zaś zdecydowanie dowiodło, iż oba parki są do siebie bardzo podobne. Autorki zatem czują się uprawnione do stwierdzenia, że ich istnienie nie jest korzystne jeśli chodzi o rozwój funkcji turystycznej na analizowanym terenie. Przy braku odpowiednich (na szerszą skalę) działań promocyjnych w świadomości wielu osób będzie utrwalał się błędny wizerunek turystyczny omawianych obszarów chronionych.

Być może warte uwagi jest podjęcie przez dyrekcje obu parków krajobrazowych wspólnej inicjatywy, której celem byłoby upowszechnienie wiedzy na temat wartości przyrodniczych i kulturowych, jak również wskazanie konkretnych kierunków rozwoju funkcji turystycznej. W opinii autorek ciekawym pomysłem na utrwalenie tych terenów w mentalności odbiorców, może być stworzenie dwóch odrębnych tematycznie (niemniej jednak uzupełniających się) produktów turystycznych.

\section{BIBLIOGRAFIA}

GOŁEMBSKI G. (red.), 1999, Regionalne aspekty rozwoju turystyki, PWN, Warszawa - Poznań.

GRZEŚKOWIAK J., 1965, Kruszwica - zarys monograficzny, Towarzystwo Naukowe w Toruniu, Toruń.

JANUSZKIEWICZ M.J., PLESKACZYŃSKI A., 2006, Księga rozmaitości wielkopolskich, WBPiCA, Poznań. 
ŁĘCKI W. (red.), 2010, Kanon krajoznawczy województwa wielkopolskiego, Bogucki Wyd. Naukowe, Poznań.

Polska niezwykła. Wielkopolska. Turystyczny atlas samochodowy, 2008, Demart SA, Warszawa.

REINFuSs R., 1962, Malarstwo ludowe, Wyd. Literackie, Kraków.

SOŁOWIEJ D., 1992, Podstawy metodyki oceny środowiska przyrodniczego człowieka, Wyd. UAM, Poznań.

SPyCHAŁA A., 2010, Funkcja turystyczna Parku Krajobrazowego „Dolina Baryczy”, Bogucki Wyd. Naukowe, Poznań.

SZTUMSKI J., 1984, Wstęp do metod i technik badań społecznych, PWN, Warszawa.

ŚWIECHOWSKI Z., 1982, Sztuka romańska w Polsce, Arkady, Warszawa.

ZAJADACZ A., 2003, Metoda analizy porównawczej potencjatów turystycznych miast, [w:] M. Pietrzak (red.), Krajobraz - turystyka - ekologia. Problemy ekologii krajobrazu, t. XI, Wyd. Naukowe Bogucki, Leszno.

http://zpkww.pl/download/128.png.

http://kruszwica.um.gov.pl/szlaki_turystyczne. 